Etnográfica

Revista do Centro em Rede de Investigação em

Antropologia

vol. $12(2) \mid 2008$

Vol. 12 (2)

\title{
Reclaiming the (Swiss) nation for God: the politics of Charismatic prophecy
}

Reclamando a nação (Suiça) para Deus: as políticas da profecia carismática

\section{Philippe Gonzalez}

\section{(2) OpenEdition}

Journals

\section{Edição electrónica}

URL: https://journals.openedition.org/etnografica/1797

DOI: 10.4000/etnografica. 1797

ISSN: 2182-2891

\section{Editora}

Centro em Rede de Investigação em Antropologia

\section{Edição impressa}

Data de publição: 1 November 2008

Paginação: 425-451

ISSN: 0873-6561

\section{Refêrencia eletrónica}

Philippe Gonzalez, «Reclaiming the (Swiss) nation for God: the politics of Charismatic prophecy», Etnográfica [Online], vol. 12 (2) | 2008, posto online no dia 04 julho 2012, consultado o 12 fevereiro 2022. URL: http://journals.openedition.org/etnografica/1797 ; DOI: https://doi.org/10.4000/ etnografica. 1797

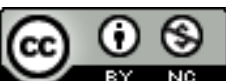

Etnográfica is licensed under a Creative Commons Attribution-NonCommercial 4.0 International License. 


\title{
Reclaiming the (Swiss) nation for God: the politics of Charismatic prophecy
}

\section{Philippe Gonzalez}

\begin{abstract}
Using an ethnographical approach, this paper examines the relationship between Charismatic prophecy found in Evangelical circles and a discourse that envisions the concept of "the (Swiss) nation" as the basis and horizon for understanding God's activity within history. We will demonstrate the intricacy of various modes of participation, ranging from ecstatic involvement in church Sunday worship and Charismatic youth meetings to citizenship in the national community. In such settings, participants are urged to connect the religious and political realms in order to restore the nation through the (re)establishment of an ancestral purity which is seen to have its source in Christianity. "Spiritual warfare" is the framework assumed by the members to perceive the issues at stake, this framework is then extended to the public domain. The analysis will try to shed light on the nature of the communities envisioned, the diverse modes of participating in them and the role of the Holy Spirit as an empowering agent for reshaping those communities and society.

KEYWORDS: category analysis, evangelicalism, dominion theology, Sociology, spiritual warfare, Switzerland.
\end{abstract}

"Bernard Rottmann les reçut aux portes de Münster dans un encombrement de
charrois, de sacs et de barils. Les apprêts du siège rappelaient l'activité désor-
donnée de certaines veilles de fête." Marguerite Yourcenar, L'Euvre au Noir

THIRTY YEARS AGO, M. MCGUIRE WROTE APROPOS THE CATHOLIC Pentecostals prayer groups she was investigating: "All of the prophecies observed and recorded were directed toward personal and interior spirituality, and occasionally there were prophecies referring to interactions within the prayer group. None of the themes of prophecies ever involved statements about the condition of larger society or involvement in that larger society" 
(1977: 144). ${ }^{1}$ At the time, the same kind of observations could have been made about Charismatic Evangelicalism. ${ }^{2}$ But things have changed. Social researchers doing fieldwork in Africa or in South America have been documenting such a shifting, following the itineraries of international prophets or apostles, as well as the implication of local clergymen with politics. ${ }^{3}$ Charismatic Evangelicals are displaying a new conception of activism where the individual's soul is not the privileged target. Instead, those Christians are reaching for collective entities such as governments or nations, declaring war to the demonic forces binding the land in order to bring spiritual revival and economic prosperity.

That shift is no longer confined to the African or the South American continents. It is spreading in the Western countries as well, as the Charismatic preachers travel around the globe to deliver their message in stadiums saturated by the crowds. Europe is part of this global network, and it does not stay immune to the prophecies cast on her nations: "all countries come to be seen as "New Israels" (Coleman 1998: 250). This spiritualized nationalism has a profound impact on the Evangelicals' conceptions of politics, the public sphere becoming a spiritual battlefield over which they have to take authority "in the name of Jesus." Thus, in his last book advocating for "Dominion theology," apostolic minister C. Peter Wagner clearly states: "It is our task to become spiritual and social activists until Satan's dominion is ended" (2008: 73).

This paper ${ }^{4}$ investigates how this emphasis on nationhood brought by the traveling prophets and other apostles is indexed in the local life of ordinary Christians. The investigation takes place in Switzerland and tries to grasp the political dimensions conveyed by the language of Charismatic prophecy, especially through the call to, or the prediction of, the Holy Spirit's action for a revival and a purification of the nation. If what circulates is a message - an intertextuality, according to T. Csordas (1997) - the interest shall reside in how

I The sociologist's findings were corroborated by contemporary studies (Fichter 1974, McGuire 1974). Catholic Pentecostal prophecy became interested in social issues in 1975, with what has become known as the "Rome prophecies" (Csordas 1997).

2 For the sake of simplicity, I adopt S. Coleman's descriptions of Charismatic Evangelicals: "emphasis on the miraculous, the power of the Holy Spirit, the development of a personal relationship with Jesus, the need to combine study of the Bible with the cultivation of experience, and the hope for a revival transcending denominational boundaries" (1998: 246). With M. Percy (1996), I would underscore the importance of supernatural words and wondrous works for this kind of religiosity, that is a fascination for (divine) power.

3 S. Ellis \& G. ter Harr (1998) provide for a first approach for Sub-Saharan Africa, as M. Marostica $(1994,2000)$ for Argentina. The book edited by A. Corten \& A. Mary (2001) is a mine on the subject and encompasses both Africa and South America. S. Francello (2007) delivers the most up-to-date descriptions of the African interweaving between Evangelicalism and politics. At the moment of writing my first article on the subject (Gonzalez 2008), I was not aware of this body of literature.

4 I would like to thank N. Genet, T. Gyger, J. Hedström, L. Kaufmann, C. Monnot and Etnográfica's anonymous readers for their helpful comments on a previous draft of this paper. 
this message becomes an embodied reality for the common believer, how it is locally transformed and performed into an intersubjective experience. Thus, the main concern of this study is to account for the ways those local believers invest the grammar of motives and the metaphors suggested to them by the foreign preachers when they speak of "revival" or "spiritual warfare."

In order to firmly anchor my study in an existing network, three related sites shall be successively investigated: a Sunday morning service in a Geneva church, a Charismatic gathering of youth groups from all over French-speaking Switzerland, and a national prayer day gathering. The starting point is always the same local congregation. The movement to the other scenes is coordinated from there: it is a trip of the youth group to a regional rally or an invitation to join a worship meeting during national holiday [fête nationale] in order to bless the country, its institutions and the Evangelical politicians. As the believers travel from one site to another, the images of revival, purity, or nation undergo a substantial shift, loosing part of their metaphorical dimension and gaining a more concrete meaning. Nevertheless, I argue that the merging is never complete between the two levels, intersubjectivity and intertextuality, the individual's body and the collective body: there is a resistance from the believer to completely identify himself with the discourses he is exposed to. As we shall see, this reluctance springs from the ordinary Evangelical "anthropology," one that is mostly individualist and centered on the production of self-identity. ${ }^{6}$

It is important that the link between the different scenes is first given by the actual believers' comings and goings. This means that the sites are naturally related and that my analysis stands or falls in its capacity to recover the "naturally occurring members' descriptions" (Emerson, Fretz, and Shaw 1995: 114), as well as their indigenous theories and ways of ordering the world. Such a focus explains the space that will be devoted to describe Charismatic events. ${ }^{7}$ But, more important, such a descriptive emphasis stems from the idea that structural shifts are accomplished in the interactional settings reported, that is during powerful ceremonies able to redefine the meaning and the purpose of being an Evangelical, the sense of what is or is not spiritual, worth of pursuing and accomplishing. The analysis to come is informed by such a pragmatic posture.

5 My approach bears evident affinities with Csordas' (1987) and with E. Claverie's (2003) pragmatic anthropology of religion. It springs from a sociological background and is influenced by D. Smith's (2005) work combining phenomenology, attention to sequential production of social order and relations of ruling, particularly the way texts inform society. My analysis also relies on H. Sacks' (2000) naturalist methods for investigating categorization and sequentiality. The interest in social mediations has been instilled in me by my late mentor and friend, Jean Widmer (2002). This article is dedicated to his memory.

6 That Evangelicalism has an individualistic "anthropology" is taken for granted by leading scholars (Fath 2005, Willaime 2004). Here, this individualism will be put under scrutiny, in particular concerning the tensions between individual and collective orientations.

7 On the importance of description in regard to theory, see B. Latour (2005) and D. Goode (1994: chapter 5). 


\section{LOCAL LEVEL: PROPHESYING REVIVAL AS A TROPE}

Whenever a foreign prophet visits a Charismatic church, it is quite certain that he or she is going to deliver a prophecy on revival coming to town. In fact, prophesying on the spiritual revival of a region or a country is a common trope, a well-worn rhetorical commonplace. Those predictions are made on several occasions, every time a visiting prophet is in town. The prophecies we are about to discuss were cast in June 2006, in a Geneva congregation where I was doing fieldwork. The topic and the content of the prophecies are quiet standard. They were delivered in English by foreign visitors, and took place at the end of the Sunday service, right after the Lord's supper. However, before turning to those prophetic speeches, I shall narrate part of the worship service in order to exhibit how the prophecies are related to the singing practices and the messages carried by the lyrics of the songs. In other words, there is a continuous work between the performance of the hymns and the casting of prophetic utterances, as the meaning of the metaphors employed is anchored in the particular setting through a dialectical process between settled text and improvised speech. Hence, the importance of giving a sequential account of what is happening during the worship service, the meaning of the images depending on their sequential positioning.

\section{Singing with all one's body and soul}

This morning, the sun is high and weather is hot. The chapel is packed: more than two hundred and fifty people are awaiting in a cheerful mood for the service to start. The room is filled with the faithful's chatter, as everyone greets her neighbor and enjoys the last minutes before the start to exchange the week's news. The windows are wide open and soon the passers-by will hear the congregation sing from across the street. At a quarter before ten, the assembly is greeted by the senior pastor, a thin relaxed man in his forties. The minister introduces the guests that will enhance the service with their music and their singing: students from a prophetic school visiting Switzerland. Though their campus is in Cyprus, they come from many Western countries, most of them being North-Americans. The pastor gives thanks to God for the sunny day and prays that it will warm everyone's heart, "Lord, lead us in worship, by your presence. Come into our hearts, we ask you in Christ's powerful name." 8

The minister's "amen" is echoed by the congregation. He then invites his audience to join into adoration, "Let's praise our God," as a student starts strumming his guitar with rhythm and conviction. Next to the musician, a

8 I translate as the service was held in French. For the sake of simplicity, I do not focus on the translation practices of the participants even though they are fascinating and contribute in a major way to the production of the phenomenon. 
choir formed by three fellow students provides for the singing. They dance behind their mikes' stands and intone: "You are beautiful in every circumstance. You are beautiful every day. And we will join with the angels singing 'Hallelujah' for the King who reigns up high." An overhead projector throws the lyrics on the wall behind the singers. People in the audience contribute to the music joyfully clapping their hands. The singers keep repeating those lyrics for a couple of minutes, before switching to French at the choir's leader instigation, a beautiful young woman with dark long hair, dressing in a white robe and gracefully holding her microphone in her hand.

After five minutes, the rhythm starts slowing down until the guitarist hits his last chord. Nevertheless, the music does not cease. Without a pause, the musician launches into a new song with fervor, embarking the whole congregation with an upbeat tempo. Once again, though the lyrics are short, the tune is carried on for a few minutes in both French and English: "Blessed be the name of the Lord, blessed be your glorious name." Everyone is standing in the chapel, part of the audience dances and claps hands, encouraged by the musicians' classmates attending the service among the congregation.

As the music intensity decreases, approaching the end of the song, the guitar player does not stop, but provides for a layer of sound behind the choir, gently playing some chords. This instills a charismatic atmosphere in the room. While some people in the audience burst into glossolalia, a student from the choir, the most preeminent male singer, delivers prophetic utterances directly translated into French by the choir's leader. Actually, not only does she translate those words, but she sings them, using the musical background as a progression for improvising, "We surely say: let your name be glorified. We wanna see your name lifted high over this city. We wanna see your name glorified in the midst of your people. Hallelujah for the Lord, our God, he reigns."

As the student keeps prophesying, more and more people in the chapel are brought into glossolalia. "Tell him we love him this morning." Most of them, the eyes shut, the hands open and raised close to the chest, slowly shake their bodies while letting a strange speech come out of their mouths. The room is saturated by the sound and seems filled by a presence, or at least by the longing for its manifestation. The bodies' motion conveys the erotic sign of the desire for this presence and expresses the reality of its coming, a loving inhabitation. The student and his singing partner keep kindling the assembly. With the help of the guitarist, they structure the audience into a choir responding "hallelujah" to the prophetic utterances. The structure is given by the rhythm of the guitar, as the young man keeps proclaiming, "For God, our Lord, the almighty, he reigns. And we wanna praise and glorify today Jesus. With one voice, we're singing for him. We join with the choir of the heaven. Hallelujah! How we love you!" 


\section{Worship: between eroticism and politics}

This short description of what happened during the first fifteen minutes of the worship service exhibits many noteworthy elements, among which are a feeling of proximity of the deity, the matters of the "prophetic utterances," the theme of power and singing as a way of taking authority, and the role played by the improvised parts, either sung or spoken. However, before turning to those elements, it is necessary to start with the way a culture is informed by hymns: they work as a script awaiting for an embodied performance. Historian S. Marini's description of early Evangelicals can thus be extended to contemporary Charismatic Christians:

Hymns have performed vital functions in evangelical religious culture. The experience of singing is central to revivalism, the characteristic evangelical ritual mode, and hearing of meditating upon hymns often mediates the new birth, the movement's classic form of spiritual experience. For all evangelicals, hymn singing has been a primary vehicle for transcendence, the very wind of the Spirit itself. Hymns have also served as educational media for children, aids to prayer for adults, homiletic devices for preachers, and literary material for poets and novelists. [...] Above all, hymns have articulated the everyday beliefs and practices of generations of $[\ldots]$ evangelicals. (Marini 2002: 273)

Worship songs give shape to both the Charismatic culture and the individual believers' experience. They function as texts circulating in the Evangelicals circles and contribute to shape the religious experience of the faithful. Those texts carry specific categories of perception, what T. Csordas (1987) calls a "vocabulary of motives" and "metaphors." Those categories are linked into a meaningful system that reveals an imagined collective horizon, that is a particular Lebenswelt that the performers of the song (as well as their listeners) are invited to enter and to inhabit. It is important to keep in mind that a preaching is generally given once by someone else, whereas tunes are repeated by oneself. Even if the sermon has been recorded and circulates on tapes or on the Internet, it does not acquire the same vividness as a song, for singing is an esthetic experience, involving not only cognitive capacities, but affective and physical ones as well. As the believer sings, he is bodily affected, his action appealing to his feelings. This means that the message carried by the tunes is invested in an emotional way and implies a kind of commitment different from that of a mental assent.

Indeed, the description of our Sunday worship exhibits the genre of emotions likely to happen as the faithful praise their deity. The erotic character of those ecstatic manifestations has already been noted by M. Percy (1997), the author rightly describing Charismatic worship as a "sweet rapture." There is a 
sense of surrender into God's loving arms, as will be noticeable in the lyrics of some of the subsequent tunes of the service. But, most of all, the things uttered by the student during the improvised parts work on the same pragmatic level as the hymns: they make embodied statements about the deity implying his presence in the room, as the believers adore him. Hence the allusions to the angelic choir and the heavens as entities co-present with the worshiping congregation: the immediacy of God is made tangible, the believers' affected bodies displaying this divine touching.

Praising appears as an important context for ecstatic exultations. Usually, collective glossolalia takes place after long moments of singing. Even so, this is not the only kind of exultations that I noticed. I also evoked "prophetic utterances," this designation being quiet problematic in view of the typical features proposed by Csordas to define the genre: "Prophecy is a first-person pronouncement in which the 'I' is God; the human speaker is merely God's mouthpiece" (1987: 453).

Nevertheless, if we consider prophecy as forth-telling, as suggested by McGuire (1977), the prophet being the one who speaks in front of the assembly in an inspired way, the difficulties seem to find a solution. This is more true if we pay attention to the actions accomplished by the utterances as they are delivered by the student, during worship: the statements seem to mingle different genres ranging from exhortations addressed to the congregation, to praise or petition prayers directed to God. This is consistent with Csordas' manner of conceiving the Charismatic genres: "Catholic Pentecostal ritual language [lies] along [a] continuum" (sharing, teaching, prayer, prophecy), "with respect to the dialectic of performer-audience interaction" (1987: 449). In this continuum, the first-person pronouncement using the "I" as God's displays, in the most univocal manner, the codes of prophecy. However, I shall argue that it is not the only way to proffer a prophetic utterance, as will become evident from the public addresses that will follow the Lord's supper. In the same way, is not "prophetic utterance" an adequate description of the ecstatic statements expressed by the student, during worship, on behalf of the congregation, through a collective "we"?

Love is not the only element evoked when addressing God. His royal attributes are proclaimed at great length. Power seems then to be one of the major qualities attributed to the deity (Percy 1996; 1998). The combining of power and proximity establishes a complex relationship with the divine entity, one made of awe for this incommensurable ruler, and of complicity: somehow, the believers share in the authority he exercises over the world. This participation in God's might is implied by statements of this sort, "We wanna see Your name lifted high over this city. We wanna see Your name glorified in the midst of Your people." Such requests indicate that the believers can ask God to act in specific ways. Notice that one of the envisaged goals is "this city," a 
geographical entity.9 "Lifting high" God's name clearly means establishing his authority upon this territory, now conceived in terms of power. Such an understanding of God's ascendancy over a land carries political overtones awaiting to be explicated. As a matter of fact, the student's utterance is more than a request: in the context of a spiritual warfare, a fight for the coming of a revival, it is an offensive launched against any other influence, mostly demonic, pretending to rule the place. Singing is fighting. ${ }^{10}$

The description of the first moments of the service, as well as the expressions about to come, demonstrate that singing shapes the religious experience of the congregation. The form displayed is mostly structured around some recurring themes: God's immediacy, love and power. But there also are improvised parts displaying short phrases. In both cases, the musicians and the singers use the musical patterns to improvise segments in a collaborative manner with the assembly. Those moments actively solicit the audience and lead to important collective spiritual experiences. This analysis is convergent with B. Jules-Rosette's work on the Apostolic church of John Maranke. The author describes the use of songs not only to manage the sequential ordering of the service, but also to reach a certain spiritual state which is viewed as a visitation of the Holy Spirit (Jules-Rosette 1975). It is to such a visitation that we now turn, as we proceed with the study of this worship service, bearing in mind that improvisation favors the anchoring of a script in the particular experience of a congregation and of the individuals it gathers, that is the collective embodiment of a text. Thus, the phenomenological experience of being filled by the Spirit goes hand in hand with the investment of meaning constructs and the phenomenal world they carry. ${ }^{11}$

\section{Weaving songs and entering an eschatological horizon}

After a short dance performance, the students of the prophetic school continue to lead the congregation in worship during more than twenty-five minutes of uninterrupted music, except for the ecstatic phenomena that will punctuate the transition from one tune to another. The guitarist will not break off his playing. On the contrary, he will work on the dynamics of the moment, closely following the choir leader's and the male singer's signs of charismatic visita-

9 See E. Schegloff's important article (1972) on formulating places in ordinary conversation. The author relies both on sequential and category analysis.

10 R. Llera Blanes (2008) evokes this fight against the demon by the means of worship, but on the individual's level. For a more elaborated argument of the political dimension of spiritual warfare, see my previous article (Gonzalez 2008).

11 I hold from P. Ricœur (1986) the idea that the projection of an interpreter into a text gives way to the advent of a new Lebenswelt, in conjunction with a new self. M. Pollner \& J. Stein (1996) reach similar conclusions in their study of Alcoholics Anonymous' testimonies. The sociologists speak of "social worlds." 
tion. The outcome of the musician's work will be to closely weave the different songs into a single temporal continuum. In this way, the musical background will not clash with the building of the collective experience.

As already noted by B. Jules-Rosette, the worship leaders play an important role during the ritual. In our case, those leaders are the ones calling, introducing, and commenting on the tunes. That their action is efficient is suggested by the way the audience responds, that is how the congregation enters into a state of collective rapture and displays the charismatic manifestations of the Spirit's presence. We shall now consider the lyrics of some of the songs that were interpreted during the second part of the service - space preventing us from giving a complete description of the entire service. We shall also describe how the prayers and the prophetic words uttered by the students leading the praise frame the perception of the message carried by those songs.

The choir leader starts with a hymn coming from the bestseller French hymnal edited by Youth with a Mission [Jeunesse en mission], a Charismatic Evangelical mission. Actually, most of the songs that were interpreted during the service come from this hymnal, by far the most popular not only within Charismatic circles, but also in most of the Evangelical French-speaking churches. However, an important number of the hymns has been translated from English, in large part those conveying an implicit theology focused both on God's immediacy, his intimacy with the believer, and the deity's power on territorial units (cities, countries and nations). ${ }^{12}$ The following tune starts on an lively guitar rhythm. While the assembly claps the hands, the lead singer shouts: "You are our joy. You are our hope. Hallelujah." She then begins the song, quickly followed by the choir and the audience.

Verse 1:

À nous la force,

la joie du Seigneur,

à nous la puissance

par son bras puissant.

\author{
Ours is the strength \\ the joy of the Lord, \\ ours is the power \\ by the arm of his strength.
}

Chorus:

Faisons monter, monter

un parfum de louange.

Let's lift up, lift up

an incense of praise.

Faisons monter, monter,

notre adoration.

Let's lift up, lift up,

our adoration.

Verse 2:

Revêtu de force,

[He] put on the strength,

entouré de gloire,

[He is] surrounded by glory,

12 For a longer description of the features of this hymnal, see my article (Gonzalez 2008). 
assis sur le trône, à la droite du Père. seated on the throne, at the Father's right.

The song is entitled "Faisons monter" [Let's lift up]. ${ }^{13}$ Its content is aimed at the believers: they are collectively affirming that theirs "is the strength". The first verse clearly revolves around the idea of power. The chorus carries the image of a thanksgiving sacrifice, the smell of the burnt offering ascending towards God's throne. This image is present in the instructions found in the Pentateuch and regulating the sacrificial rites. ${ }^{14}$ It is also found at the end of the New Testament, where it refers to the prayers of the faithful: "Another angel, who had a golden censer, came and stood at the altar. He was given much incense to offer, with the prayers of all the saints, on the golden altar before the throne. The smoke of the incense, together with the prayers of the saints, went up before God from the angel's hand." (Revelation 8: 3-4) The horizon disclosed by this song is strongly saturated by biblical metaphors and exhales an eschatological flavor. This apocalyptic horizon is a recurring theme that runs through the rest of the worship service.

The singing does not end, but the tune is rapidly supplanted by an improvised leitmotiv: "You are holy, three times holy." After several repetitions, the motive changes based on a prophetic utterance sung by one of the choir students. Soon the congregation starts to sing "Jesus is the King of glory, the almighty." As the music decreases, the choir leader prays accompanied by the layers of sound provided by the guitar. She beseeches: "Oh, yes, come Lord! We are nothing without you. Come Lord! Set our hearts on fire!" And, full of fervor, she launches into a new song imploring the coming of the Holy Spirit. ${ }^{15}$

Verse 1:

Saint-Esprit, entends mon cri. Holy Spirit, listen to my cry.

J'ai soif de ta présence. I thirst for your presence.

Je te cherche et te désire. I seek you and desire you.

Après toi je soupire. I sigh for you.

Chorus:

Oh règne en moi.

Règne en moi.

Oh reign in me.

Reign in me.

13 This hymn was composed by R. Fernandez and bears number 621 in the JEM2 (my translation).

14 As God prescribes the building of the tabernacle to Moses, he includes the instructions for an incense altar: "Make an altar of acacia wood for burning incense. [...] Aaron must burn fragrant incense on the altar every morning when he tends the lamps. He must burn incense again when he lights the lamps at twilight so incense will burn regularly before the LORD for the generations to come." (Exodus 30:1, 7-8; NIV)

15 I have not been able to locate this tune in any of the major French-speaking Evangelical hymnals (my translation). 
Verse 2:

Que ton feu vienne sur moi

May your fire come upon me

et embrase ma vie.

and set my life in fire.

Purifie et sanctifie tout ce

que je suis.

Purify and sanctify all

that I am.

This hymn exhibits typical features of filling by the Spirit and awakening. It combines fire and water images. Obviously, both elements have a purifying effect and describe a passionate love: while fire carries the idea of becoming inflamed, water refers to the thirsting for the loved one. This analysis is similar to M. Percy's, as he studied the musical repertoire of the Toronto blessing, one of the major Charismatic revivals of the 1990's:

the metaphors used to describe the (ideal) revivalist church reveal an interesting fascination with passion. Typically, the blessing of God is described as being 'channeled' through water or fire. Thus, revival is 'rain', 'a river', 'wave', 'refreshing' and the like: the task of the church and the individual believer is to become 'soaked' in this. (Percy 1997: 83)

The choir leader will spin out the water metaphor as she launches the next song, a call for revival: "Let it rain. Open the flood gates in heaven." As the song ends in a powerful charismatic exultation, the glossolalic responses by the assembly filling the whole room, the singer says: "Send your Holy Spirit on Geneva! We are thirsty for your presence. Come, Lord Jesus!" And suddenly, she paraphrases one of the most famous apocalyptic statements of the entire Bible, indexing it on the local context: ${ }^{16}$ "We join with the church in Geneva and say, "Come, Lord Jesus!" The woman, a metaphorical bride, a living incarnation of the church, keeps imploring her lover, on the verge of tears, as if she was about to faint: "Come, Lord Jesus! Come, Lord Jesus!" The worship moment ends on a longing.

\section{Prophecies of revival}

After the Lord's supper, two students from the prophetic school are invited to say a few words. The minister of the church introduces this moment as a short time of "testimony." Nevertheless, the speeches are more akin to prophecies than to sharing. My analysis shall focus on the communication of the messages, rather than on their reception by the audience. In comparison to the ecstatic responses displayed by the congregation during the singing, the

16 “The Spirit and the bride say, 'Come!' And let him who hears say, 'Come!' Whoever is thirsty, let him come; and whoever wishes, let him take the free gift of the water of life. [...] Amen. Come, Lord Jesus." (Revelation 22:17, 20b; NIV). 
interaction with the assembly is more difficult to apprehend for the analyst when a single speaker is addressing a silent crowd. The translation brought another interference with the delivery of the messages. The student responsible for translating his colleagues into French experienced some understanding difficulties to the extent that a member of the audience had to step on the stage to take over translating. Yet, these incidents are not detrimental to the study of the prophetic phenomena, since our interest focuses on the way the descriptions and the type of actions implied for the people are addressed by the students' speeches.

None of the addresses exhibit the use of the first-person pronouncement as God's "I." However, they present clear prophetic features, particularly by way of the motifs and of the metaphors invoked, those relying largely on the hymns previously sung or coming from the Bible. The Scriptures play an important role in the addresses under study, each speaker quoting a passage from the New Testament and applying it to the local situation. This is probably a move to grant authority to their discourse and the reason no "thus speaks the Lord" prefaces their statements. (It is important to keep in mind that those are students from a prophetic school.) The speeches address the same theme: God's revival is coming. Likewise, they follow a very similar structure: (a) a greeting; (b) a few words on the country visited and the students activities during the visit; (c) a biblical quotation related to the interaction with the hosting congregation; (d) an assurance, for the addressees, of God's coming (to town or to the country); (e) an "amen" concluding the speech. The first speaker is a girl in her twenties:

Bonjour famille! [Hello family!] Our School in Cyprus has been praying for Switzerland for five months now. So it's such a pleasure to finally be here with you and see your faces. As we've been praying, we're sure of the Lord's great love and his call for Switzerland. That he has called this nation to be fire-carriers with a message to awaken Europe.

How many of you felt his presence this morning during worship?

((People in the audience raise their hands.))

Amen! That's what it's about. That's what knowing Jesus is all about. We've been witnessing in the streets for a couple of weeks now. We were just in Germany. And again and again, as we speak with the young people we find that many of them are very familiar with the Scriptures. What we need to be and what we need to pray for others is for a sensitivity to the Holy Spirit.

I saw a scripture in Luke. It's a small parable about a Pharisee and a tax collector. The Pharisee, he was very arrogant. [...] And then the Lord says: "Everyone who exalts himself and tries to be impressive will be humbled. And those who humble themselves will be exalted, be lifted up." So that's just my prayer. 
I just heard that the churches in Switzerland are uniting for prayer. That happened earlier this month. So I just praise the Lord for what he is about to do in this nation and the shakings that are gonna come. I'd just like to pray quickly for this congregation.

Father, I thank you so much Lord God for ((sigh)) for what it means to follow you God. For the hope that is within us. Thank you for your Holy Spirit that is alive and active in our hearts, God. And Father, we just ask that you would breathe on us this morning. Lord awaken our spirits to love you more, so that we can love others. Thank you God that you're a faithful God and that we're gonna see you come to our generation. Amen.

Among the noticeable features of this speech, the relevant categories for addressing the audience belong to a geographical categorization device (Sacks 1974; Schegloff 1972). Country or continent names ("Cyprus," "Germany," "Europe") are used to describe the activities carried out by the parties. Those activities being religious, they imbue the solicited categories. In other words, God becomes interested in those units: he shows a "great love [...] for Switzerland". Much more, "nation" is a unit allowing to understand the deity's purpose and his action in the world: "He has called this nation to be fire-carriers with a message to awaken Europe." It appears that the speaker's enunciative footing is both configured by her relational disposition towards the audience she is addressing - a visitor talking to locals - and configuring the properties of the categorization device she is using - by way of its use, the device acquires a religious meaning.

The speech is saturated by eschatological motives drawn from the Scriptures. There is a sense of urgency in the words delivered and in the task proposed to the congregation. Soon, the Spirit's fire will be ignited among the nations, because God is about to return ("we're gonna see you come to our generation"). The mention of the "shakings that are gonna come" clearly refer to an apocalyptical horizon. The student's address exhibits the features of a prediction and pertains to a specific genre of prophecy, that of foretelling. What is interesting here, is that those predictions are stated in an indirect way, precisely not as a "thus says the Lord" and without any emphasis on the speaker's "I" as being God's. Instead, the girl favors the use of a "we" referring to the prophetic school in which she can include herself. And though she is making a calling herself, she states it as a collective discernment and even more as a bare fact, God's deliberation, “we're sure of the Lord's great love and his call for Switzerland. That he has called this nation to be fire-carriers with a message to awaken Europe." In other words, not only does the student foretell what is going to happen, she indirectly transmits a call coming from the deity.

Right after this first "testimony," the male singer who shouted the prophetic utterances during the worship returns to the stage to deliver his message. The 
end of his speech will be greeted by a thunderous applause ignited by his comrades, whereas the congregation will show less enthusiasm.

Good morning! What a blessing it is to be here with you this morning and to break bread with you!

On Friday, the team, we all took a tour of the city. We went and saw some of the old cathedral and where the Reformation was. And I was struck with the inheritance and the past that you have here in Geneva. You have such a rich inheritance here, and I wanna encourage you with that today.

In Philippians one, verse six, Paul writes: "Being confident of this, that he who began a good work in you will carry it on to completion until the day of Christ."

I wanna point out one thing about the scripture, that is that we often use this verse for individuals. But Paul is writing to the church in Philippians. And I want to encourage the church in Genève, that you have a mighty inheritance in here. And I want to encourage you that the Reformation was not the completion of God's work in Geneva. It was only the start. And this morning when I was praying - I want to encourage you about - I felt so stirred. I feel stirred even now like I could prophesy a book over this whole church. But the one thing that I do want to prophesy, is that there is a movement of God that is coming to Geneva, that is going to make the Reformation seem minuscule. The fire of God is going to return to Geneva soon.

And I want to encourage you as Paul did with Timothy. Paul wrote to Timothy: "Concerning the prophecy spoken over you, fight the good fight." What I wanna encourage you today is that the fire of God has been prophesied over Geneva. Fight the good fight with that. Pray and intercede for the fire of God to return to Geneva. Because it's coming and he wants to pour out here. Be blessed. Amen.

The student states his prophecy according to the same indirect lines of his schoolfellow. Note the passive form: "the fire of God has been prophesied over Geneva." The enunciative footing is identical to the one adopted by his predecessor. The purpose of the prophecy is to "encourage the church" in Geneva. At least, he tries to support this particular assembly where he is delivering his prediction. Again, a geographical location becomes relevant as a recipient of God's action. Even so, there is more: a historical inheritance is summoned to describe the mission of the revival about to come, a past where Christians were in control of the city.

The student speaks of the "mighty inheritance" of the church in Geneva. He directly evokes the $16^{\text {th }}$ Century Reformation, probably having Calvin's work in mind. The speaker describes the Reformation as a Golden Age in Geneva's history. It is the origin of the "mighty inheritance" and a paradigm of the action of God among a particular people. At the same time, the speaker declares 
this Reformation incomplete in regard to the coming revival. The interest in appealing to that historical setting, is that it evokes a mythical past in which church and society were closely intermingled. It evokes a time during which "real" Christians, the Protestants were the overwhelming majority - in fact the single authorized religion. It also refers to a period when those Christians were responsible for the city, that is the political realm. So the envisioned horizon seems to combine elements of religious homogeneity with political overtones.

However, something has apparently gone wrong since that Golden Age. Today's situation is not displaying religious homogeneity. That is where the "fire of God [is] returning" to town. The metaphor of the fire seems to carry eschatological overtones: the fire destroying the impurities of sin. That destruction is to be linked to the fight metaphor. The audience in the church has to take sides in this fight, praying for the divine fire to come. Obviously, the prophet is alluding to the spiritual warfare opposing God and his armies, the church being part of it, to the demonic forces. Another eschatological element is the outpouring of God's Spirit, here on the people of Geneva. This is a positive aspect of the fire of God: the burning hearts of those who receive the Holy Ghost and are, therefore, purified and committed to Christ. In other words, the Spirit comes to purify the hearts of those living in Geneva, and through that action, he gives back the Christian heritage of the city. Here again, a religious movement potentially implies political effects.

At the end of this section, we must keep in mind that the intended goal of the prophet is to encourage an assembly. Therefore, we should not press too hardly the implicit meanings that we detect in the language of revival used by this prophet. First and foremost my analysis seeks to show the potentialities of those metaphors dealing with revival, purity of the hearts and of the nation, and outpouring of the Spirit. However, if at this local level, revival prophecies are a commonplace topic evoked by prophets on their way, when we change scales, the metaphors start being filled up differently and lead to other kinds of involvements. The balance between the metaphorical and the literal meanings of figures of speech such as "people" or "nation" is altered. Soon, the analysis will show how those metaphors are unpacked in bigger settings.

\section{Beyond Reformation and revivalism: shifting eschatologies}

Before leaving the local setting, it is necessary to make two remarks about the Reformation and the kind of revivalism expected. Those remarks shall throw some light on the role played by the prophet in Dominion theology and reveal some important shifts in the Charismatic understanding of eschatology.

The prophecies analyzed, especially the last one, make strong statements concerning what is about to come. As he prophesies, the singer states that the "movement of God that is coming to Geneva [...] is going to make the Reformation seem minuscule." This is congruent with the historical 
interpretation advocated by the supporters of the "New Apostolic Reformation," which is said to have started in 2001 and is "the most radical change in the way of doing church since the Protestant Reformation" (Wagner 2008: 34). This does not make of our student an advocate of Dominion theology, but shows that the idea of something exceeding the Protestant beginnings is widespread and that some Charismatic leaders are systematizing it.

As he explains this "New (or Second) Apostolic Reformation," Wagner clearly links it with three offices which recently surfaced in the Charismatic world: "intercessors," in the 1970s, who aimed at using "the spiritual authority God has given them to bind and neutralize demonic powers;" "prophets," coming in the 1980s, who, thanks to the work of the intercessors, "can hear from God more accurately and communicate that message to the Body of Christ;" and, in the 1990s, "apostles" who "take the word of the Lord from the prophets (and [...] also, of course, hear from God directly) [...] and they assume leadership in implementing it". Now, the advent of this new "governmental infrastructure" equips the church for accomplishing its goal: "transform cities, nations and other social units" (Wagner, 2008: 26-27, 39-40).

Therefore, the prophets play a definite part in the plan to take dominion over the different spheres of society and hold a certain position in the chain of command that implements such a goal. At the same time, the prophet announcing the Spirit's outpouring is instilling a very different meaning to the apocalyptical "Come, Lord Jesus" (Revelation 22:20). This is not Hal Lindsey's The Late Great Planet Earth or Tim LaHaye's Left Behind series with their pessimistic eschatology advocating for the rising of the Antichrist, the rapture before the tribulation, the battle of Armageddon, and Christ's millennial reign from Jerusalem. The revival announced by our student prophets is more akin to an empowerment of Christians leading to the establishment of God's reign on Earth as a prelude to Christ's return. "Come, Lord Jesus" is then closer to "Give us power and authority on Earth", as was congruent with the content of the Sunday service I just described. And, once again, this shift in eschatology is found in Wagner's theology:

We no longer accept the idea that society will get worse and worse, because we now believe God's mandate is to transform society so it gets better and better. [...] "Before Jesus returns, the Church will rise in glory, unity, and maturity. The Kingdom of God will grow and advance until it fills the Earth." (Wagner 2008: 61)

But, there is an important qualification as I point those shifts in eschatology. If they seem crystallized in Wagner's writings, the author having adopted a "Victorious eschatology", it does not necessarily follow that the local churchgoer will embrace such a view. Actually, the issue is more complex than holding to 
this or that doctrine about the end of times. What seems to be the case, according to my ethnographic observations, is that a believer can simultaneously hold different eschatological beliefs, even incompatible ones from the point of view of an external observer. Furthermore, labeling such practices as "cognitive inconsistency" totally misses the point, for the plasticity of eschatological language authorizes this kind of ambiguity and, more important, situated use. The main concern of the believer resorting to this kind of language is not doctrinal consistency, but locally accomplished relevance: "how does it help us/me understand what we are/I am living here and now?" Again, the semantic properties of the theological terms provide much pragmatic room for maneuver, this fact explaining the ability to switch back and forth from one paradigm to the other.

\section{REGIONAL SPHERE: TRAINING PROPHETS}

The next data were collected during a charismatic gathering held by youth groups in March 2006. It lasted three days, from Friday evening to Sunday afternoon. A thousand of teenagers and young adults attended the event. They came from different towns of the French-speaking part of Switzerland, that is Suisse romande or Romandie. One of the groups belongs to the Geneva church where the preceding prophecy was cast. I was allowed to film the youth gathering during my fieldwork. The following excerpts come from a workshop on prophesying given by one of the key speakers, on Saturday afternoon. A hundred of people were present. The two sequences take place during the first eight minutes of the workshop.

\section{The paradigm of the 9/11 prophet}

The lesson is given by a German "prophetess" (the quotation marks referring to the way she was introduced to the audience). She instructs her audience on the role of the Charismatic prophet and how to prepare oneself to become a channel for God's prophecy. She is being translated from German to French. Since the audience was French-speaking, I choose to work on an English rendering of the French. The workshop lasts for one hour and a half. The first excerpt happens right after the prophetess' prayer asking God to fill the room and taking authority against any kind of hypocrisy or opposition towards the prophetic flow. Before the prayer moment, she spoke briefly on one of the main attributes of the prophets: being able to distinguish the pure from the impure. As will be demonstrated, those categories of purity and impurity drastically shape the understanding of the prophet's role.

01 Les prophètes sont aussi des gens qui savent distinguer les moments, qui savent quand c'est le moment de faire quoi. // Prophets also are people who can distinguish between the times, who know when it is the time to do what. 
02 Et Dieu dit aussi qu'il ne fait rien, rien dans cette Suisse romande, / / And God also says that he does nothing in this French-speaking Switzerland

03 sans qu'il le dise avant à ses serviteurs, les prophètes. // without first telling his servants, the prophets.

04 Aux États-Unis, il y a un Juif, // In the United States, there is a Jew,

05 un simple ouvrier. // a simple worker.

06 Et Dieu lui a dit: "Prie ce verset dans Jérémie // And God told him, "Pray that verse in Jeremiah

07 où il est écrit: 'Appelle-moi et je vais te révéler des choses incroyables'." // where it is written, 'Call me and I will reveal you incredible things',"

08 Il a prié ça pendant trente jours avec sa famille. // He prayed that for thirty days with his family.

09 Et ensuite Dieu lui a dit: "Écris un livre!" // And then God told him: "Write a book!"

10 Et puis il a simplement inventé une histoire. // And then he simply made up a story.

11 Il ne savait même pas que c'était une vision de Dieu qu'il avait reçue. // He didn't even know that it was a vision from God that he had received.

12 Il a écrit un livre gros comme ça. // He wrote a book thick like this.

13 Et d'une manière surnaturelle, il a trouvé un éditeur. // And in a supernatural manner, he found a publisher.

14 Et après le onze septembre, // And after September the eleventh

15 ce livre a été un best-seller. // that book became a bestseller.

16 Parce qu'il a écrit mot à mot // Because he wrote word for word

17 ce qui s'est passé le 11 septembre a New York. // what happened on September the eleventh in New York.

18 Et maintenant Dieu lui a de nouveau montré quelque chose, // And now God is showing him things again,

19 quelque chose sur l'islam. // things about Islam.

20 Il est un homme comme tout le monde // He is just like everybody else

21 et il a obéi à Dieu. // and he obeyed God.

22 Il a tout simplement fait ce qu'il a dit. // He simply did what he said.

23 Et logiquement cet homme est maintenant invité partout en Amérique // And logically that man is now invited everywhere in America.

24 CIA l'a scanné totalement. // CIA scanned everything from him.

25 "Mais d'où sais-tu tout ça?" // "From where do you know all this?"

26 Il n'y a donc rien que Dieu ne dise pas avant à ses serviteurs les prophètes? // Is there anything that God doesn't tell his servants the prophets?

27 Voulez-vous être des gens pareils // Do you want be people like that,

28 auxquels il confie quelque chose? // to whom he entrusts something? 
It is not possible to go into the details of these data. Yet, I shall point noteworthy elements about this sequence. It is composed of three parts: (a) a preface stating a prophet's characteristic and his role in God's action in Suisse romande [01-03]; (b) a paradigmatic narrative about a Jewish prophet who foretold the 9/1 I events [04-26]; (c) a question inviting the audience to identify herself with this exemplar prophet [27-28].

The interactional shape displayed by this sequence is a complete unit. It opens with the preface and closes with the last question, which on the performative level has more to do with an invitation than with an inquiry. The preface can be further divided into a general statement on one of the prophet's attribute, his ability to discern the times [01], and the way God works with his prophets in French-speaking Switzerland [02-03]. Actually, the mention of the Suisse romande works on two planes: on one side, it indexes what will be said in the regional context, and on the other side, it functions as a universal rule. God always entrusts his prophets with revelations, and that includes this specific part of Switzerland. ${ }^{17}$

God is present in the world through his prophets. The ending of the sequence confronts the audience with the possibility of becoming a vehicle of this presence: "Do you want to be people like that, to whom [God] entrusts something?" [27-28]. The combination between the general statement and the question leads to a role offering, that is the offer to be a prophet. Now what kind of person is that supposed to be? Here the central part of the sequence is going to fill up the categories of, and linked to, the prophet.

This central portion [04-26] introduces the audience with the paradigm of a powerful prophet. Interestingly, this paradigm does neither come from the Old nor from the New Testaments. Another fascinating feature is that he is not a Christian, be it Evangelical or else. He is a simple common Jew living today in the USA. Thus, the participants are invited to identify with somebody from another religion-but not any religion-one that has strong affinities with Christianity and is highly valued among Charismatic and Fundamentalist circles. (The same could be said of the nation mentioned, USA. At least is it implied by the speaker.) This prophet receives a vision from God, and, through a supernatural chain of events, is able to foretell what will happen on 9/1 1. His prophecy is so successful that he is invited everywhere in the States to give conferences. Even the CIA is depicted as eager to find about the origin of his knowledge [24-25]. So, here is our paradigm: a prophet successfully predicting

17 The generality of this divine mandate is more evident in the German, where the prophetess says, "Und Gott sagt auch dass er nichts tut auf diese Erde - tut nichts in diese Französisch sprechende Schweiz - nichts, ohne dass er erst vorher sein Knecht, den Propheten sagt." [And God also says that there is nothing he does on this Earth - does nothing in this French-speaking Switzerland - nothing, without first telling to his servant, the prophet.] 
major sociopolitical events to such an extent that he becomes an issue of, and a counselor for, national security.

If we look with attention at the way categories are used in this narrative, we start to understand where the menace comes from and who are the allies. The later are easier to establish: they are the ones receiving vision, that is Jews and (Evangelical) Christians. They also are the ones God is assisting through his prophet, that is the USA and the Western nations. Facing this coalition, we find Islam: "And now God is showing [his prophet] things again, things about Islam" [18-19]. That goes along with the imputation of the responsibility about the 9/1 l events. The Muslims are not beneficiaries of God's prophecy. They do not reveal God's secrets: their secrets are revealed by others, Jews and Christians. Not only is the audience invited to turn into a bunch of mighty prophets addressing issues of national security, it is also requested to take side in the conflict opposing some categories - "Jews", "Christians", "USA", "French-speaking Switzerland" - to others - "Islam".

\section{Speaking to the leaders and purification}

The second sequence occurs within minutes from the preceding one. It shows how the political program of prophecy is to be implemented and linked with the idea of purification.

01 Et je crois que Dieu, ça lui tient à c'ur que la prophétie puisse grandir. // And I think that God, it is close to his heart that prophecy can grow.

02 Que Dieu aimerait que les gens en Suisse romande puissent aller chez les conseillers fédéraux, les directeurs et puissent leur dire des choses de la part de Dieu. // That God would like people in Suisse romande to go to the Federal Councillors, to the Chief Executive Officers and tell them things of God's behalf.

03 Et Dieu a des solutions pour tout. // And God has solutions for everything.

04 Il a pour tout une idée. // He has ideas on everything.

05 Et vous êtes des gens auxquels il veut confier ça. // And you're people to whom he wants entrust that.

06 Vous croyez ça? // Do you believe it?

07 Vous voulez ça? // Do you want it?

08 C'est quelque chose qui est absolument nécessaire pour la prophétie, // It is something which is absolutely necessary for prophecy,

09 que Dieu vienne avec une purification complète. // for God to come with a complete purification.

10 Aujourd'hui je voulais parler du thème: comment marcher dans la lumière. // Today, I wanted to talk about the theme: how to walk in the light. 
The structure of the sequence articulates general statements [01-04] with an invitation to commitment [05-07]. That combination is followed by a general conclusion on the importance of purification for prophecy [08-09]. Finally, a new sequence starts introducing the main topic of the workshop, this topic being closely linked with the concept of purification. A more careful look at this excerpt will make explicit the ties between the different parts.

The prophetess starts by stating that God wishes the growth of prophecy [01]. She immediately explains her thought exposing that such a growth will lead on to prophets becoming advisers to the Swiss government and the economical leaders [02]. That "God has solutions for everything" has important implications for democracy. This conception of prophecy seems to court with theocracy and is at least pervaded by the biblical narratives describing a close collaboration between the king and the prophet in Ancient Israel. That is the achievement of a full-grown prophecy. But how to attain it?

Such a growth is achieved by a complete purification of the prophet. That he or she is the intended subject of the purification is evident from the main topic of the workshop "how to walk in the light" [10]. If the prophet is to discern between the times, he or she is to distinguish light from darkness, right from wrong, in order to lead a moral life and lead others in this same kind of life. This moral purity allows the prophet to become God's channel for the nation. The idea of purification is then closely related to that of revival. The moral purification is one essential aspect of a new commitment to God. In the case of the prophet, the nation benefits from his or her morality in that it receives prophecies. There is a direct impact of the prophet's virtue on the national well-being, an impact leading to the purification of the country. The prophet is at the same time the mediator of God's presence among, and a metonymy of, the nation.

We reach very similar conclusions to those concerning the local church in Geneva: the category describing the origin of the audience is treated as spiritually relevant for explaining God's action in the world. Thus, the political and economical leadership of a regional entity, Suisse romande, becomes a spiritual issue. Through the idea of purification, the metaphor of revival allows the passage from the individual and church spheres to the regional and national spheres. We go from the purification of the hearts to the purification of the nation.

Once again, this analysis needs to be qualified considering the attitude of the people participating to the workshop. Taking notes in the back of the room, I could hear some of my neighbors commenting negatively on the teaching. They did not understand the point about purifying oneself and the need of publicly confessing one's sins. One of the ladies beside me whispered, "I came to prophesy, not to tell about my troubles." At the end of the class, I could notice that this frustration was widespread among the participants. It lasted until the day after, when the prophetess allowed everyone 
who wished to stand, move forward, and prophesy in the microphone. This episode exhibits different expectations from the parties involved: the prophetess awaits the coming of a generation of powerful spiritual leaders able to influence society, whereas the participants wish to have an individual experience of delivering a message from God, a way of self-fulfillment.

\section{In command and at war}

Among the many elements exhibited by the prophetess' speech, I retain three central elements. First, the paradigmatic prophet occupies a special position in the chain of the deity's revelation to the church, but as well to the secular leaders, that is a political influence. Secondly, the prophet's mission is to promote the advancement of God's kingdom. Such an advancement has to do with purification, which is an encompassing program were the Christian, as an individual and as a member of a collective body (the church), struggles against evil forces to redeem himself and his or her country. This collective exorcism takes place in worship gatherings were believers reclaim their destinies and the nation's "in Jesus' name". Until here, we have the usual ingredients of spiritual warfare.

But there is more. Thirdly, waging war becomes less and less metaphorical as specific religious categories ("Muslims") are drawn up into lines with the evil forces, while Christians and Jews are presented as the axis of good. The discourse about purification carries worrying resonances. The prophetess attributes to (categories referring to) actual human beings what was said before of a repulsing other, the demon. Thus, there can only be confrontation with the Muslim, since he is acting on behalf an evil entity, except if he converts, abandoning his otherness to become one of "ours". Prophetic speech gives way to a divine approval of the clash between civilizations.

\section{NATIONAL SPHERE: PURIFYING AND LEADING THE NATION}

The third and last site I describe has been taking place annually since 2001, during the Swiss national holiday, on August the First. The event is organized by Prière pour la Suisse [Prayer for Switzerland], an Evangelical para-ecclesial organization seeking to rebuild a Christian Swiss identity. It is a national gathering open to all the churches aiming to pray for the country. They claim to gather six thousand people. The event resembles a Charismatic meeting with worship, preaching, and so forth. However, several elements differ from an usual meeting: Evangelical Members of the Swiss Parliament and politicians are invited and blessed, flags of every Swiss Canton receive a blessing as well. Everything is directed towards Switzerland's prosperity and spiritual revival. I first analyze a flyer advertising for the 2006 gathering, before showing how political and religious networks are interrelated by means of Prayer for Switzerland. 


\section{Cleaning the nation}

I found the Prayer for Switzerland prospectus on the display of the Geneva church where I was doing fieldwork, and subsequently in several of the assemblies that I visited. The background of the handbill is white. In the foreground, we see a Swiss cross made of granite. In the center of the cross, the outline of Switzerland geographical borders has been carved. The nation lies then at the center of the cross. On the upper part of the flyer, a motto is written, "God passionately seeks your heart." "God" and "seeks" are red, whereas the rest of the words are black lettered. Once again, the language refers to love and passion, the same kind of emotions encountered during the worship moments. Were it only for the locution, there would be nothing new. Yet, there is something new: the language of passion conflates here with that of national identity. Intimate love then becomes public. Therefore, God is not only seeking individuals' hearts, but also the heart of the nation.

In order to reach those hearts, God has to clean them. Here we find the biblical verse chosen for the event, in the back of the flyer, inside a red box and written in white (those being the colours of the Swiss flag): "I will sprinkle clean water on you, and you will be clean; I will cleanse you from all your impurities and from all your idols." The verse is taken from an Old Testament prophet (Ezekiel 36: 25). Once again, the outpouring of water is the mean to achieve purification, a metaphor of the coming of the Holy Ghost. A closer look at the addressee of the verse, as it is inserted on the prospectus, reveals an ambiguity. As is evident in French, the "you" addressed by the verse is a plural. Now this "you" simultaneously addresses a group of believers and envisions a country. The Christians have become the emanation of the nation. To them is entrusted the task of purifying Switzerland, through the water (and the fire) of the Spirit.

\section{Blessed are the Elect(ed)}

Praying for the Evangelical politicians and Members of Parliament is a way to state that they have been chosen by a higher power than that of democracy. Indeed, they were democratically elected, but were they not providentially chosen? Are they not God's Elect for protecting and retrieving the nation's Christian inheritance? Such conceptions lead us to the heart of a new paradigm, the conceptual shift undertaken by Evangelical spiritual leaders. They did not let go of individualism, and simultaneously they do not cling to it as they used to. Theirs is a new vision combining both individual and collective aspects, that of putting committed individuals at strategic places in order to spread their (Christian) influence. This is the gospel according to Wagner: "The rules of the democratic game open the doors for Christians who have Kingdom values, to move into positions of leadership influential enough to shape the whole nation from top to bottom" (2008: 15). Furthermore, in order 
for the elected to listen carefully to the Kingdom values, they will need the help of the Charismatic intercessors, prophets, and apostles, those chosen by the Spirit, for they are the ones to whom God reveals his plans.

Such networking between "intercessors" and politicians is already taking place. Since 2001, the same year when Prayer for Switzerland started its rallies, one of the leading members of this same organization and soon-to-be the president of the Swiss French-speaking Evangelical Alliance, Jean-Claude Chabloz, answered the divine call to become the freelance intercessor for the Swiss Parliament. From then on, he has been working to sensitize Evangelicals to the importance of praying for, and lobbying the political authorities. The Prayer for Switzerland meetings have been a way of involving ordinary churchgoers in, and giving publicity to, such a vision. The effectiveness of this sensitization can probably be seen in the expansion of the Swiss Evangelical Party [Parti évangélique suisse] traditionally implanted in the German-speaking part of the country. In 2006 and 2007, two branches were created in French-speaking cantons, one in Neuchâtel and another one in Geneva. Since November 2007, the Evangelicals are part of the biggest coalition in one of two chambers of the Parliament, along with the Christian Democrats and the Green Liberals. ${ }^{18}$

\section{DISCUSSION}

I have shown how metaphors of revival carry potential political overtones and how those potentialities are actualized in different settings. The shift in the meaning of the metaphors is subtle to such an extent that the participants often do not see what is at stake. They seldom notice that their Christianity is more and more mingling spiritual and political dimensions, through their quest for power. If my analysis is accurate, this shift is partly caused by a problematic use of geographical and political categories. At the same time, it results from a theological change in the perspective of some Evangelical figures, such as C. Peter Wagner. Yet, certain aspects of this phenomena need further investigation, among which the politicization of the believers, in order to show how their religious practice is translated into political behaviour and adherence to a social movement or a party. Thus, it is necessary to shed more light on the local networks that effectively bridge the gap between religion and politics, even if those dimensions are more and more blurred for Evangelicals themselves.

From what I have seen until now, this conversion from believer to political activist has few chances to succeed, that is to convert the 100,000 Swiss Evangelicals into supporters of the Evangelical parties. This judgement is based on

18 The Swiss Evangelical Party holds two seats, while this center-right coalition amounts to 36, most of them being Christian-Democrats. 
my ethnographic fieldwork: often have I had the feeling that ordinary participants were more interested in experiencing the deity's presence by the means of a major worship gathering, a Durkheimian "effervescence collective," than in the political message offered to them by their religious leaders. The reason for this lack of appeal lies probably in the "anthropology" carried by the ordinary Charismatic, one interested in the individual's self-affirmation and also found among Catholic Pentecostals:

Anthropological accounts of traditional societies customarily treat ritual as a window on the nature of society, as events that throw light on underlying cultural and structural patterns: society creates ritual as a self-affirmation. In a movement like Catholic Pentecostalism, this relation between society and ritual is inverted. Ritual events like prayer meetings are both historically and structurally prior to the generation of distinctive patterns of thought, behavior, and social organization. The events provide the earliest models for the organization of aspects of community life transcending the boundaries of the events: ritual creates society as a self-affirmation. (Csordas 1987: 448)

Two antagonist "anthropologies" seem to be competing at this moment in Swiss Charismatism. On one side, there is the individualist vision classically held by Evangelicalism; on the other, we find emerging theological discourses about what it means to be a collective. That the Evangelicals become more aware of themselves as a political entity will depend on which one of these "anthropologies" becomes the dominant paradigm. This article has tried to exhibit how Charismatic prophetism contributes to accomplishing such a shifting.

\section{REFERENCES}

CLAVERIE, Élisabeth, 2003, Les Guerres de la Vierge. Une Anthropologie des Apparitions. Paris, Gallimard.

COLEMAN, Simon, 1998, "Charismatic Christianity and the dilemmas of globalization", Religion, 28, pp. 245-256.

CORTEN, André, and André MARY (eds.), 2001, Imaginaires Politiques et Pentecôtismes: Afrique/Amérique Latine. Paris, Karthala.

CSORDAS, Thomas J., 1997, "Prophecy and performance of metaphor", American Anthropologist, 99 (2), pp. $321-332$.

—, 1987, "Genre, motive and metaphor: Conditions for creativity in ritual language", Cultural Anthropology, 2 (4), pp. 445-469. 
ELLIS, Stephen, and Gerrie ter HARR, 1998, "Religion and politics in Sub-Saharan Africa", The Journal of Modern African Studies, 36 (2), pp. 175-201.

EMERSON, Robert M., Rachel I. FRETZ, and Linda L. SHAW, 1995, "Pursuing members' meanings", in Writing Ethnographic Fieldnotes. Chicago, The University of Chicago Press, pp. 108-141, 226-230.

FATH, Sébastien, 2005, "Les protestants évangéliques français. La corde raide d'un militantisme sans frontière”, Études, 403, pp. 351-361.

FICHTER, Joseph H., 1974, "Liberal and conservative Catholic Pentecostals", Social Compass, 21 (3), pp. 303-310.

FRANCELLO, Sandra, 2007, “Gagner les nations à Jésus': Entreprises missionnaires et guerre spirituelle en Afrique”, Social Sciences and Missions, 20, pp. 82-98.

GONZALEZ, Philippe, 2008, "Lutter contre l'emprise démoniaque. Les politiques du combat spirituel évangélique”, Terrain, 50, pp. 44-61.

GoODE, David, 1994, A World without Words. The Social Construction of Children Born Deaf and Blind. Philadelphia, Temple University Press.

JULES-ROSETTE, Benetta, 1975, "Song and spirit: The use of songs in the management of ritual contexts", Africa: Journal of the International African Institute, 45 (2), pp. 150$-166$.

LATOUR, Bruno, 2005, "On the difficulty of being an ANT: An interlude in the form of a dialog”, in Reassembling the Social. An Introduction to Actor-Network-Theory. Oxford, Oxford University Press, pp. 141-156.

LLERA BLANES, Ruy, 2008, "Satan, agent musical. Le pouvoir ambivalent de la musique chez les Tsiganes évangéliques de la péninsule Ibérique”, Terrain, 50, pp. 82-99.

MARINI, Stephen, 2002, "Hymnody as History: Early Evangelical hymns and the recovery of American popular religion", Church History, 71 (2), pp. 273-306.

MAROSTICA, Matthew, 2000, "La nueva política evangélica: el movimiento evangélico y el complot católico en la Argentina”, Ciencias Sociales y Religión/Ciências Sociais e Religião, 2 (2), pp. 11-30.

_ 1994 , "La Iglesia Evangélica en la Argentina como nuevo movimiento social”, Sociedad y Religión, 12, pp. 3-17.

MCGUIRE, Meredith B., 1977, “The social context of prophecy: 'Word-gifts' of the spirit among Catholic Pentecostals”, Review of Religious Research, 18 (2), pp. 134-147.

— 1974, "An interpretive comparison of elements of the Pentecostal and Underground Church movements in American Catholicism", Sociological Analysis, 35 (1), pp. 57-65.

PERCY, Martyn, 1998, "Fundamentalism and power", in Power and the Church. Ecclesiology in an Age of Transition. London and Washington, Cassell, pp. 59-80.

—, 1997, "Sweet rapture: Subliminal eroticism in contemporary charismatic worship", Theology and Sexuality, 3 (6), pp. $71-106$.

_., 1996, Words, Wonders and Power: Understanding Contemporary Christian Fundamentalism and Revivalism. London, SPCK.

RICCEUR, Paul, 1986, "La fonction herméneutique de la distanciation”, in Du Texte à l'Action. Essais d’Herméneutique II. Paris, Seuil, pp. 113-149.

SACKS, Harvey, 2000, Lectures on Conversation. Volumes I \& II. Oxford and Cambridge, Blackwell.

— 1974, "On the analysability of stories by children", in Turner Roy (ed.), Ethnomethodology. Selected Readings. Harmondsworth, Penguin Books, pp. 216-232. 
SCHEGLOFF, Emanuel A., 1972, "Notes on a conversational practice: Formulating place", in David Sudnow (ed.), Studies in Social Interaction. New York and London, The Free Press and Collier-Macmillan Limited, pp. 75-1 19, 432-433.

SMITH, Dorothy E., 2005, Institutional Ethnography: a Sociology for People. Walnut Creek, AltaMira Press.

WAGNeR, C. Peter, 2008, Dominion! How Kingdom Action Can Change the World. Grand Rapids, Chose.

WIDMER, Jean, 2002, "Symbolic power and collective identifications", in Stephen Hester, and William Housley (eds.), Language, Interaction and National Identity: Studies in the Social Organisation of National Identity in Talk-in-Interaction. Aldershot, Ashgate, pp. 102-143.

WILLAIME, Jean-Paul, 2004, "Le statut et les effets de la conversion dans le protestantisme évangélique”, in Sébastien Fath (ed.), Le Protestantisme Évangélique. Un Christianisme de Conversion. Turnhout, Brépols, pp. 167-178.

YOURCENAR, Marguerite, 1991 [1968], L'Euvre au Noir. Paris, Gallimard.

Reclamando a nação (Suíça) para Deus: as políticas da profecia carismática - Philippe Gonzalez - Département des Sciences de la Société (University of Fribourg, Switzerland). Institut Marcel Mauss/Groupe de Sociologie Politique et Morale (École des Hautes Études en Sciences Sociales, Paris, France) • philippe.gonzalez@unifr.ch

Empregando uma abordagem etnográfica, este artigo analisa a relação entre o profetismo carismático desenvolvido nos círculos evangélicos e um discurso que molda o conceito de "nação" (suíça) como fundamento e horizonte para a compreensão da aç̧ão de Deus através da história. Procuraremos demonstrar a complexidade e embrenhamento dos distintos modos de participação, que alternam entre o envolvimento extático no culto dominical e nos encontros das juventudes carismáticas, e a participação de cidadania na comunidade nacional. Nestes contextos, os participantes são convidados a interligar a esfera religiosa e política, de forma a poder restaurar a nação através do (re)estabelecimento de uma pureza ancestral que é encontrada no cristianismo. O enquadramento assumido pelos crentes para poder entender o contexto que os rodeia é o de "guerra espiritual", que por sua vez se desloca para o domínio público. Esta análise procurará, finalmente, compreender a natureza das comunidades divisadas, os distintos modelos de participação nas mesmas e o papel do Espírito Santo como agente empoderador para a reconfiguração da sociedade.

PALAVRAS-CHAVE: análise categorial, evangélicos, teologia da dominação, sociologia, guerra espiritual, Suíça. 